\title{
REVISED Case Report: Cerebral leukodystrophy and the gonadal endocrinopathy: a rare but real association [version 2; peer
} review: 2 approved]

\author{
Mohammad Humayun, Abidullah Khan (iD)
}

Khyber Teaching Hospital, 25000, Peshawar, Pakistan

V2 First published: 07 Feb 2018, 7:158

https://doi.org/10.12688/f1000research.13933.1

Latest published: 23 Apr 2018, 7:158

https://doi.org/10.12688/f1000research.13933.2

\section{Abstract}

A 30 year old married Pakistani woman presented in January 2018 with an eight month history of progressive left sided weakness, ataxia, spasticity, underdeveloped secondary sexual characteristics and primary infertility. She was the elder sister of a 19 year old bed bound woman who was diagnosed with vanishing white matter (VWM) disease 12 months previously. The MRI scan of the brain demonstrated diffuse leukodystrophy and her hormonal assays were significant for premature ovarian insufficiency. Results from her genetic tests demonstrated a point mutation in eukaryotic initiation factor 2B (EIF2B). Thus, she was the second confirmed case of VWM from her family of 12 siblings with normal parents.

\section{Keywords}

Vanishing white matter, neuro-ovarian failure, leukodystrophy

\section{Open Peer Review \\ Approval Status \\ 1 \\ 2 \\ version 2 \\ (revision) \\ 23 Apr 2018 \\ version 1 \\ 07 Feb 2018

$\checkmark$
view
view
$?$ \\ 1. Jeremy Chataway, University College London, London, UK \\ 2. Bernard Corenblum, University of Calgary, \\ Calgary, Canada}

Any reports and responses or comments on the article can be found at the end of the article.

Corresponding author: Abidullah Khan (dr.abidullahk@gmail.com)

Author roles: Humayun M: Conceptualization, Investigation, Supervision; Khan A: Conceptualization, Supervision, Writing - Original Draft Preparation, Writing - Review \& Editing

Competing interests: No competing interests were disclosed.

Grant information: The author(s) declared that no grants were involved in supporting this work.

Copyright: @ 2018 Humayun M and Khan A. This is an open access article distributed under the terms of the Creative Commons Attribution License, which permits unrestricted use, distribution, and reproduction in any medium, provided the original work is properly cited.

How to cite this article: Humayun $\mathrm{M}$ and Khan $\mathrm{A}$. Case Report: Cerebral leukodystrophy and the gonadal endocrinopathy: a rare but real association [version 2; peer review: 2 approved] F1000Research 2018, 7:158 https://doi.org/10.12688/f1000research.13933.2 First published: 07 Feb 2018, 7:158 https://doi.org/10.12688/f1000research.13933.1 


\section{REVISED Amendments from Version 1}

The new version includes the following;

1) The term 'premature menopause' has been replaced with 'premature ovarian insufficiency'

2) More details have been provided regarding the reproductive and sexual history of the case concerned.

See referee reports

\section{Introduction}

Van der Knaap described a new clinical entity of neuro-ovarian failure in 1996 as vanishing white matter(VWM) disease ${ }^{1}$. This rare entity is also known as ovarioleukodystrophy and is caused by a mutation of the eukaryotic initiation factor $2 \mathrm{~B}$ (EIF2B) ${ }^{2}$. It most commonly presents in infants or early childhood as a progressive central neuronal failure causing limb weakness, spasticity, cognitive decline, seizures, encephalopathy and ultimately death ${ }^{2,3}$. The onset in adults is very rare and in female patients, is frequently associated with premature ovarian failure ${ }^{3}$. In March 2017, we reported the first ever case of VWM affecting a 19 year old woman from Pakistan ${ }^{4}$. Herein, we report the case history of her elder sister diagnosed as VWM in January 2018.

\section{Case report}

A 30 year old Pakistani woman, presented in January 2018 with an eight month history of progressive left side weakness in pyramidal distribution. She had developed spasticity in the left lower limb and had partial contractures affecting both of her hands. Since the previous month, she felt clumsy in her right arm and leg. She had cerebellar signs and bilateral optic atrophy. However, the rest of her cranial nerves, the spine and the sensory system were normal. She was married for the last four years and had never conceived. Her menstrual cycles began at the age of 17 years. Her initially normal four-weekly cycles became more irregular five years down her menarche leading first to oligomenorrhea and then secondary amenorrhea at the age of 25 years. She had underdeveloped secondary sexual characteristics. Her mental state examination was normal. There was no precedent history of any trauma, surgery, malignancy or infection.

Her MRI brain scan was remarkable for diffuse leukodystrophy (Figure 1 and Figure 2). Her hormonal assays were

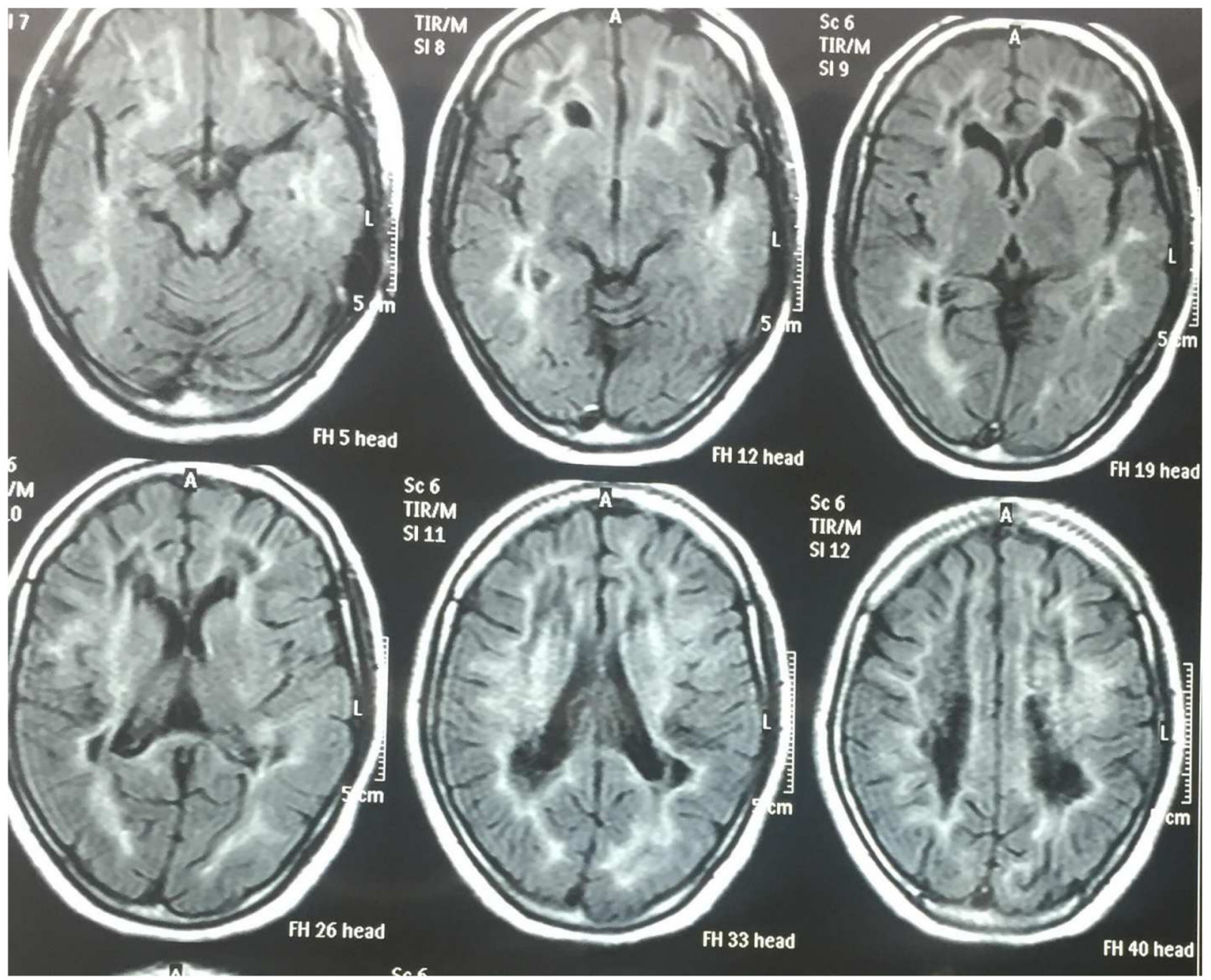

Figure 1. Cross-sectional view of T-2 weighted imaging with FLAIR demonstrating loss of cerebral white matter. 


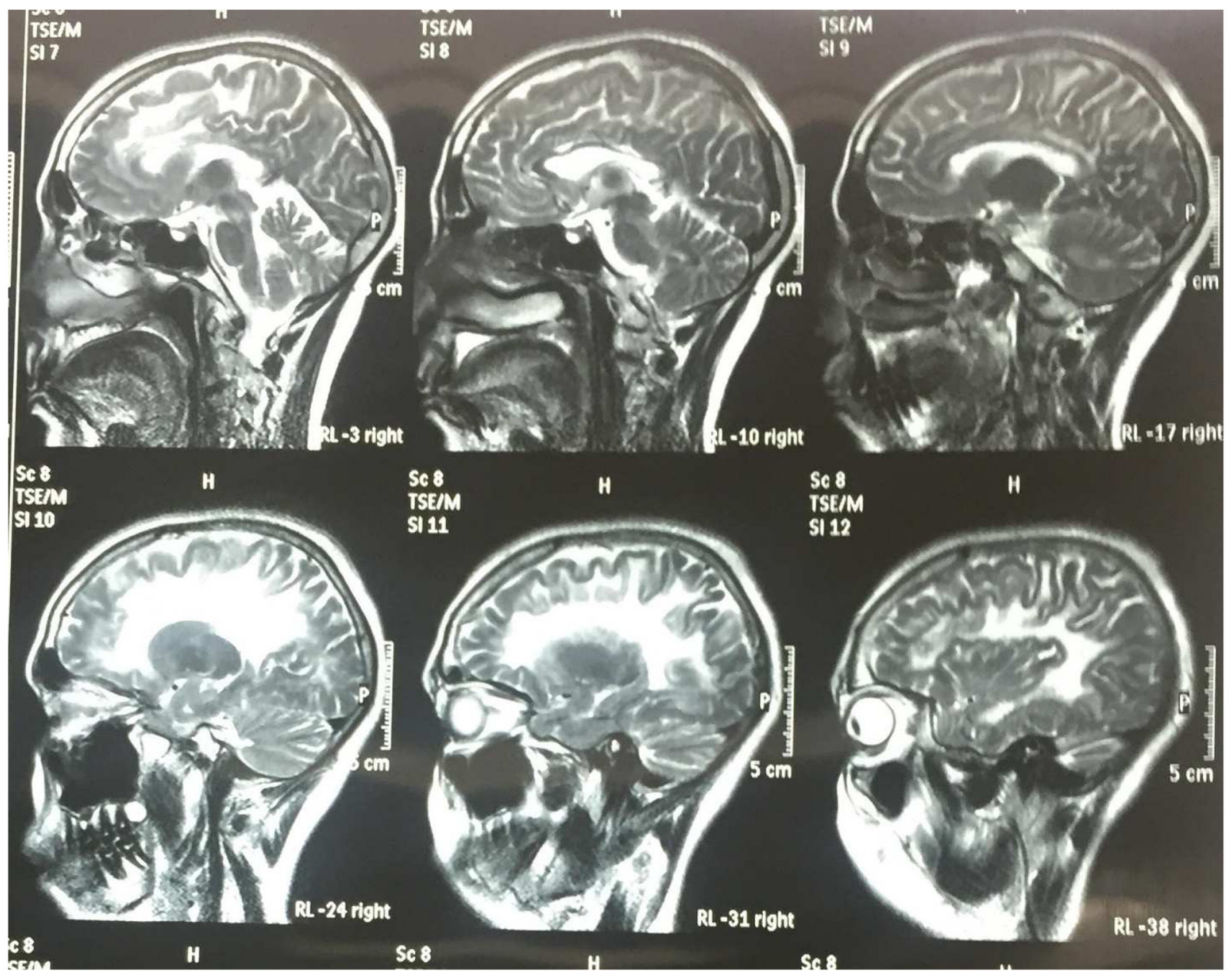

Figure 2. Saggital view of T-2 weighted images of the brain without FLAIR.

consistent with premature ovarian insufficiency (Table 1). An ultrasound of her abdomen and pelvis was remarkable for small ovaries and uterus. Her lumbar puncture results were normal and there were no oligoclonal bands in her cerebrospinal fluid (CSF). She underwent genetic tests including sequence analysis and polymerase chain reaction (PCR), which demonstrated a point mutation in the EIF2B4 gene. Thus, she was diagnosed as a second case of VWM from the same family of 12 siblings and 2 parents. None of the family members were screened due to affordability issues.

She was counseled and vaccinated against the common pathogens. She was prescribed baclofen $20 \mathrm{mg} /$ day and clonazepam $0.5 \mathrm{mg} /$ day for her spasticity. She will be reviewed again in 6 months time. The follow-up plan includes a detailed physical assessment and a repeat MRI brain scan.
Table 1. Laboratory results for Hormonal Assays.

\begin{tabular}{|l|l|l|}
\hline Test & Results & Normal Range \\
\hline $\begin{array}{l}\text { Follicular Stimulating } \\
\text { Hormone (FSH) }\end{array}$ & $143 \mathrm{mlU} / \mathrm{ml}$ & $1.5-12.4 \mathrm{mlU} / \mathrm{ml}$ \\
\hline $\begin{array}{l}\text { Luteinizing } \\
\text { Hormone (LH) }\end{array}$ & $57.21 \mathrm{mlU} / \mathrm{ml}$ & $1.7-8.6 \mathrm{mlU} / \mathrm{ml}$ \\
\hline Total Estrogen & $5 \mathrm{pg} / \mathrm{ml}$ & $50-300 \mathrm{pg} / \mathrm{ml}$ \\
\hline
\end{tabular}

\section{Discussion}

Ovarioleukodysptrophy or vanishing white matter disease (VWM) is a rare autosomal recessive disorder. It has central neuronal presentation in the form of progressive ataxia, spasticity, and variable optic atrophy in combination with endocrinopathy 
manifesting as premature ovarian failure ${ }^{3,4}$. This disease has protean spectrums of presentation ranging from the most severe prenatal and infantile forms to the relatively less severe adult onset varieties ${ }^{5}$. Our second patient had the adult onset disease, a phenotype similar to her younger sister.

The mildest of all, the adult onset variant of VWM presents with a combination of neurological features including pyramidal weakness, cerebellar signs and optic atrophy in association with premature ovarian failure ${ }^{4,5}$. The sensory system, the cognitive function and the rest of the cranial nerves are relatively spared, at-least initially ${ }^{4}$. Our patient presented with limb weakness, ataxia and visual loss in association with primary infertility due to ovarian failure. Her presentation was different from her younger sister in that, she did not have seizure or dementia ${ }^{4}$.

The diagnostic workup includes MR imaging of the central nervous system which demonstrates diffuse and cystic degenerative loss of the deep cortical white matter and U-fibers. The grey matter is preserved ${ }^{3,5,6}$. This is due to a mutation in EIF2B which causes impairment of protein synthesis under conditions of cellular stress like infection, trauma, intense emotions and surgery. The genetic tests confirm the diagnosis ${ }^{6}$. Those females who live into adulthood develop ovarian failure ${ }^{2,4,6}$. Interestingly, according to our literature search, primary testicular failure has not been described in any reported case of affected males.
Treatment is largely palliative and preventive. This may include avoidance of stressors, vaccination, anti epileptic drugs and hormonal replacement therapy in affected females ${ }^{4,5,7}$.

\section{Conclusions}

VWM is a rare but potentially serious disease. In adult females, premature ovarian insufficiency is characteristic. There is no effective treatment.

\section{Consent}

Written informed consent for publication of her clinical details and/or clinical images was obtained from the patient.

\section{Data availability}

All data underlying the results are available as part of the article and no additional source data are required.

\section{Competing interests}

No competing interests were disclosed.

\section{Grant information}

The author(s) declared that no grants were involved in supporting this work.
1. van der Knaap MS, Barth PG, Gabreëls FJ, et al: A new leukoencephalopathy with vanishing white matter. Neurology. 1997; 48(4): 845-55. PubMed Abstract | Publisher Full Text

2. Schiffmann R, Moller JR, Trapp BD, et al:: Childhood ataxia with diffuse central nervous system hypomyelination. Ann Neurol. 1994; 35(3): 331-40. PubMed Abstract | Publisher Full Text

3. Pronk JC, van Kollenburg B, Scheper GC, et al: Vanishing white matter disease: A review with focus on its genetics. Ment Retard Dev Disabil Res Rev. 2006; 12(2): 123-8.

PubMed Abstract | Publisher Full Text

4. Khan A, Humayun M, Ayub M, et al:: Vanishing White Matter (VWM) Disease presenting As Neuro-Ovarian Failure. J Coll Physicians Surg Pak. 2017;
27(3): S41-2.

PubMed Abstract

5. Labauge $\mathrm{P}$, Horzinski L, Ayrignac $\mathrm{X}$, et al:: Natural history of adult-onset elF2B-related disorders: a multi-centric survey of 16 cases. Brain. 2009; 132(Pt 8): 2161-9.

PubMed Abstract | Publisher Full Text

6. Horzinski L, Huyghe A, Cardoso MC, et al:: Eukaryotic initiation factor 2B (elF2B) GEF activity as a diagnostic tool for EIF2B-related disorders. PLOS One. 2009; 4(12): e8318.

PubMed Abstract | Publisher Full Text | Free Full Text

7. Turón-Viñas E, Pineda M, Cusí V, et al:: Vanishing white matter disease in a Spanish population. J Cent Nerv Syst Dis. 2014; 6: 59-68. PubMed Abstract | Publisher Full Text | Free Full Text 


\section{Open Peer Review}

\section{Current Peer Review Status:}

\section{Version 2}

Reviewer Report 24 April 2018

https://doi.org/10.5256/f1000research.15905.r33345

(C) 2018 Corenblum B. This is an open access peer review report distributed under the terms of the Creative Commons Attribution License, which permits unrestricted use, distribution, and reproduction in any medium, provided the original work is properly cited.

\section{Bernard Corenblum}

Division of Endocrinology \& Metabolism, Department of Medicine, University of Calgary, Calgary, $A B$, Canada

My minor concerns were adequately addressed.

I have no concerns with the revised edition, and recommend it being accepted.

I personally did learn from this report.

Competing Interests: No competing interests were disclosed.

Reviewer Expertise: Reproductive endocrinology / pituitary disease

I confirm that I have read this submission and believe that I have an appropriate level of expertise to confirm that it is of an acceptable scientific standard.

\section{Version 1}

Reviewer Report 12 April 2018

https://doi.org/10.5256/f1000research.15146.r32796

(C) 2018 Corenblum B. This is an open access peer review report distributed under the terms of the Creative Commons Attribution License, which permits unrestricted use, distribution, and reproduction in any medium, provided the original work is properly cited.

\section{Bernard Corenblum}

Division of Endocrinology \& Metabolism, Department of Medicine, University of Calgary, Calgary, 
$A B$, Canada

Premature menopause is a term no longer accepted. Premature ovarian insufficiency is used now.

The endocrine aspect of this case is the hypogonadism due to ovarian failure. No speculation is given as to the association, but perhaps none is known.

She presented at age 30, older than most, including her sister, yet was sexually immature in development.

There should be more detail on the reproductive history: onset of menarche, cycle history, when did this change, etc. This phenotype appears to be a spectrum with this case later in onset than usual, so more details are needed to extend the data base on this clinical association.

Is there any relationship with adrenal insufficiency?

Is the background of the case's history and progression described in sufficient detail? No

Are enough details provided of any physical examination and diagnostic tests, treatment given and outcomes?

Partly

Is sufficient discussion included of the importance of the findings and their relevance to future understanding of disease processes, diagnosis or treatment?

No

Is the case presented with sufficient detail to be useful for other practitioners?

Partly

Competing Interests: No competing interests were disclosed.

I confirm that I have read this submission and believe that I have an appropriate level of expertise to confirm that it is of an acceptable scientific standard, however I have significant reservations, as outlined above.

Author Response 15 Apr 2018

Abidullah Khan, Khyber Teaching Hospital, 25000, Pakistan

We thank Dr.Bernard Corenblum for his precious time in reviewing our manuscript. The points raised by him are praise worthy and we did our best to address his concerns. The points addressed in the light of his recommendation will definitely improve the quality of our article.

1. The term 'premature menopause' has been rephrased as 'premature ovarian insufficiency'. 
2. More details have been provided regarding her reproductive history including onset of menarche, cycle history and the time they changed.

3. There is no association with adrenal failure. Association of adrenal failure with leukodystrophy is a second well defined entity called as 'adreno-leukodystrophy'. Thanks again.

Competing Interests: No competing interests were disclosed.

Reviewer Report 22 March 2018

https://doi.org/10.5256/f1000research.15146.r30650

(C) 2018 Chataway J. This is an open access peer review report distributed under the terms of the Creative Commons Attribution License, which permits unrestricted use, distribution, and reproduction in any medium, provided the original work is properly cited.

\section{Jeremy Chataway}

Queen Square Multiple Sclerosis Centre, Institute of Neurology, University College London, London, UK

This report look at Vanishing White Matter disease (VMD), part of the genetically inherited leukoencephalopathies, a rare group of neurological disorders, of which X-linked adrenoleukodystrophy is the most common $(1 / 17,000)$. VMD is an autosomal recessive disorder characterised by progressive neurological impairment and white matter cystic degeneration. It generally presents in childhood but adult cases are well reported.

Here a 30 year old woman reports a short duration of weakness, ataxia and primary infertility. An older sister also has VMD (there are siblings in total).

In females there can be ovarian failure, which is a useful diagnostic feature, as is shown here (so it can be described as an ovarioleukodystrophy). The periventricular white matter shows the same signal intensity as CSF on FLAIR/T2 weighted imaging. Mutations occur in any of the 5 genes that code for translation initiation factor EIF2B (EIF2B1 - EIF2B5), here is EIF2B. Sometimes deterioration is triggered by physical or emotional trauma.

This is a useful addition to the literature of a very rare group of conditions.

\section{References}

1. Ahmed RM, Murphy E, Davagnanam I, Parton M, et al.: A practical approach to diagnosing adult onset leukodystrophies.J Neurol Neurosurg Psychiatry. 2014; 85 (7): 770-81 PubMed Abstract |

Publisher Full Text

Is the background of the case's history and progression described in sufficient detail? 
Yes

Are enough details provided of any physical examination and diagnostic tests, treatment given and outcomes?

Yes

Is sufficient discussion included of the importance of the findings and their relevance to future understanding of disease processes, diagnosis or treatment?

Yes

Is the case presented with sufficient detail to be useful for other practitioners?

Yes

Competing Interests: No competing interests were disclosed.

Reviewer Expertise: Neurology - white matter disorders

I confirm that I have read this submission and believe that I have an appropriate level of expertise to confirm that it is of an acceptable scientific standard.

The benefits of publishing with F1000Research:

- Your article is published within days, with no editorial bias

- You can publish traditional articles, null/negative results, case reports, data notes and more

- The peer review process is transparent and collaborative

- Your article is indexed in PubMed after passing peer review

- Dedicated customer support at every stage

For pre-submission enquiries, contact research@f1000.com

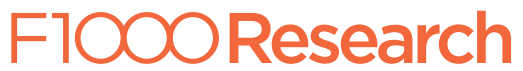

